\title{
Adoption of Integrated forms of Support for Family-Provided Care of Senior Citizens in a Selected Location in the Czech Republic
}

\author{
Petra Formánková ${ }^{1, *}$ and Lenka Mat'hová ${ }^{1,2}$ \\ ${ }^{1}$ External Postgraduate Student at the University of South Bohemia in České Budějovice, Faculty of Health \\ and Social Studies, Jírovcova 24, 37004 České Budějovice, Czech Republic \\ ${ }^{2}$ External Postgraduate Student at the University of South Bohemia in České Budějovice, Faculty of Health \\ and Social Studies, Emy Destinové 46, 37005 České Budějovice, Czech Republic
}

\begin{abstract}
Abstarct: The primary focus of this paper is to outline how integrated forms of support are applied to unofficial care providers who provide care of senior citizens in the administrative region of Písek - a municipality with extended area of operation. The result of the quantitative survey provides information on how families who provide care to senior citizens in their natural home environment make use of the possibilities of professional health and social support provided in the territory of the respective self-administration entity. Also, the survey reveals what services would ease work for these unofficial care providers. The survey was done from $8 / 2010$ to $11 / 2011$ with 475 unofficial care providers. The outcome of the survey is the need for extending the professional services provided to smaller municipalities and rural agglomerations, so that "dead spots" in the Písek region can be filled.
\end{abstract}

Keywords: Family-provided care, home care, senior citizen, social service planning, social services.

\section{INTRODUCTION}

The aging society is indisputably a contemporary social phenomenon. A rapidly aging population causes a number of social, health and economic problems. In the majority of cases, senior citizens suffer from polymorbidity, resulting in their increased reliance on the environment. A vital element in care assurance is the family, which is irreplaceable in the caretaking field. Family-provided care of senior citizens is one of the most frequent models adopted by contemporary society despite the fact that the caretaking method, structure of caretakers and their profile show certain differences. Also different are the ways in which family caretakers provide care - financial support, services, etc. [1]. Western European countries have embraced the historically primary model. Family caretakers provide care to their relatives despite the frequent psychological, physical, social and financial burden, because placing a senior in a retirement home is often understood as a last resort. The care provided by the family rests upon solidarity across generations [2]. It has a number of diverse aspects. Firstly, it represents care for love, which is what makes this characteristic irreplaceable [3]. It is different from institutional care in the sense that as much of it is provided as is really needed [4]. Secondly, this method fills the gaps and handles emergencies where there is a lack of medical and social services [5].

*Address correspondence to this author at the University of South Bohemia, Faculty of Health and Social Studies, Czech Republic; Tel: + 420777297 740; E-mail: Formankova.p@seznam.cz
With respect to the current development of priorities, the importance of supporting social services aimed at helping families is increasing, because it is the families who significantly ease and often directly enable seniors to stay in their natural environment [1]. Efficient coordination of the service provided can be ensured by planning social services on the local or regional level [6]. The so-called community plan of social services is the result of an active collection of information regarding the needs of persons in the same location and a search for ways to satisfy these needs by utilizing available resources [7]. Such plans can achieve diversity in the supply of social services [8]. Current Czech legislation offers a wide range of services and support for non-self-sufficient persons and senior citizens. Large-scale changes were initiated by act No. 108/2006 coll. on social services which came into effect on January 1, 2007. Among other things, this act governs the terms and conditions of the entitlement to care provision designated for individuals dependent on the care of another person. Thanks to a financial contribution allocated (divided into four levels) from the public budget, the recipient can decide how to use this allocation and what services and from what entity he/she wants to order [9].

The needs of Czech senior citizens can currently be satisfied on a comprehensive basis in their natural, home environment in multiple ways [10]. Widely preferred and adopted is the community care model as a form of integrated care and help, the objective of which is to enable non-self-sufficient persons to live an independent life in their own household with the help of the family and community services as long as this way 
appears to make sense and be practical [11]. Community care involves professional health care indicated by the attending physician $[12,13]$ to provide help mostly for activities of daily life (ADL). The care is generally provided along with other services of a medical nature, i.e. replacing bandaging on wounds, giving medication, prevention, rehabilitation and palliative care, social care and assistance corresponding to the current needs diagnosed for clients and their environment [12, 13]. This help involves instrumental activities of daily life (IADL) [1]. Finally, community care also includes non-professional assistance in the field of self-care, modified by the current situation in the family and by the social climate [12]. The integration process for medical and social services within the provision thereof is of particular importance [14]. The final choice of specific services is conditioned mostly by the extent to which the abilities of the person affected - the non-self-sufficient person shall be preserved and also by e.g. the scope, availability and character of the social and medical services offered, the options and preference of the caretakers from the family, etc. In principle, a decision shall be made whether to use the services of a respective institution, provide necessary family care or combine these two [10].

\section{METHODOLOGY}

The primary objective of this paper was to map out how integrated forms of support are applied to family providers who provide care of senior citizens in the administrative region of Písek. A partial objective was to determine what integrated forms of support are adopted by the family caretakers for the provision of necessary help to their close relatives and what services the family caretakers lack if they wish to provide care for senior citizens in the region in question.

Quantitative research was adopted due to the focus of the research. A questioning and questionnaire methodology was applied in the methodical research procedure. The questionnaires were designed for the family members providing care to seniors within the administrative region of the below-mentioned Písek municipality with extended scope of operation. A basic pool of all family caretakers in the respective region was used for selecting a respondent sample based on random stratification and by using a PC program ("OK nouze" program), designated for the agenda related to care provision contribution. The reason for this was that the author of this paper works with this agenda in the Social Department.

The following criterion was set for respondent selection: family members providing help to persons aged 65+ who draw a care contribution. For the selection, emphasis was laid on an even representation of respondents living in Písek - a municipality with extended scope of operation (i.e. type III municipality) and the surroundings (type I and type II municipalities). The questionnaire intended for family caretakers contained a total of nine questions, out of which eight were closed and one semi-open. The comprehensibility of the questions was first verified within pre-research ( $\mathrm{n}$ $=10)$.

Data was collected from $8 / 2010$ to $11 / 2011$ in the territory of the administrative region of the belowmentioned Písek municipality as part of the inspections regarding the drawing of the care contribution. The author decided that it would be more beneficial if she questioned the respondents and noted down their answers herself. Opting for the form of a structured interview was more time-consuming, but in this way the author had the opportunity to answer any possible questions from the unofficial care providers, explain expressions they did not understand and make them familiar with the social services offered by act No. $108 / 2006$ coll. on social services. It was also important that the respondents know for whom they were completing the questionnaire, because the author of the text had visited them several times before within the proceedings of granting a social care contribution to these individuals. The research pool counted 475 respondents. The respondents were divided into three groups based on the size of the municipality in which the senior to whom they are providing care is resident (type III municipality: 209 respondents, type II municipality: 121 respondents, type I municipality: 145 respondents). The empirical data collected was processed through descriptive statistics (absolute and relative frequency). The program Microsoft Excel was used for data processing. The data was verified by double entering and a subsequent check and correction. The data is expressed in percent or as absolute values. The results are arranged in tables and charts.

The pool investigated contained 102 men, i.e. $21.5 \%$, and 373 women, i.e. $78.5 \%$. As for the age structure of the pool, most respondents (232, i.e. $48.8 \%$ ) were aged $45-59$ and 126 respondents, i.e. $26.5 \%$, were aged $60-74$. The respondent group aged 
18-44 totaled 65 respondents, i.e. $13.7 \%$ and the group of those aged over 75 totaled 52 , i.e. $10.9 \%$. The majority, i.e. $281(59.2 \%)$ respondents were living in a joint household with a senior to whom they were providing care. The remaining 194, i.e. $40.8 \%$ of respondents, were living separately from the person they were providing for.

\section{RESULTS}

As the form of support often cumulates for unofficial care providers, the chart shows the frequency of respondents' answers. It is clear that the overwhelming majority (i.e. 352) of family members taking care of a senior citizen are supported by their own family. An alarming finding is that 92 respondents are not supported by anyone with anything. Only 57 respondents make use of assistance from organizations providing professional social services and 23 respondents from organizations providing professional medical services. Support by neighbors is used to a lesser extent (as reported by 28 respondents).

Chart 2 provides answers only from those respondents who answered in the previous question that they are using professional services for the provision of necessary help to a senior in the home environment. As the unofficial care providers may use more than one service at once, the chart quantifies the frequency of answers by respondents. Regardless of the size of the municipality where the senior is staying, the family caretakers mostly use caretaking services, as reported by 44 respondents. Ten respondents use

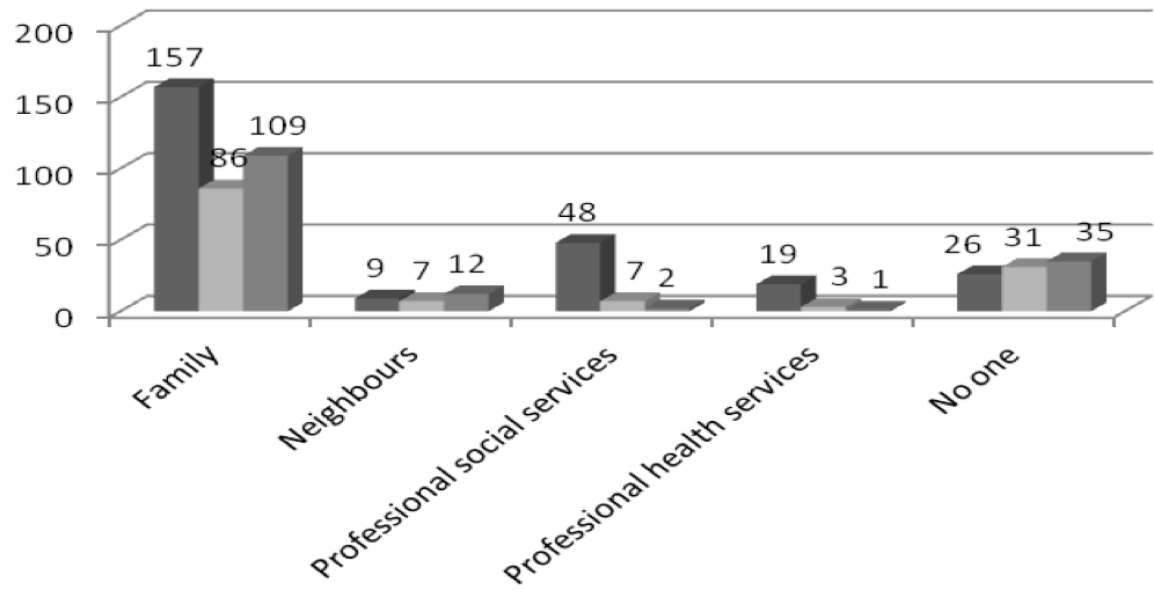

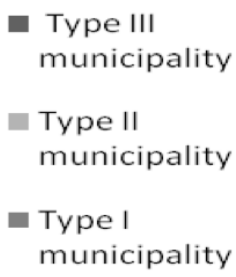

Type municipality

Chart 1: Use of integrated forms of support in the territory of Písek - a municipality with extended scope of operation (in absolute values).

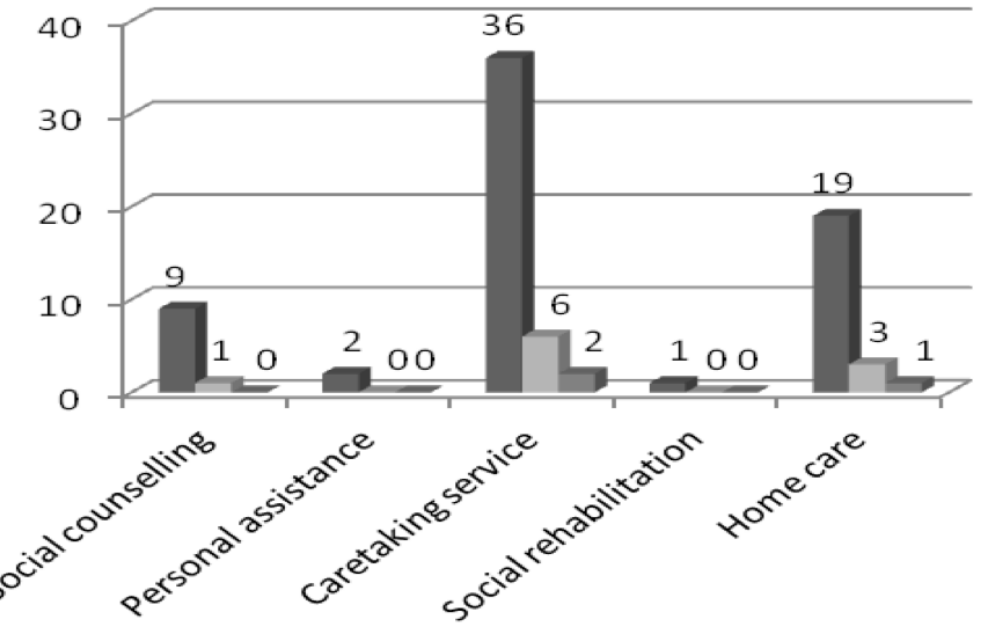

Type III municipality

- Type II municipality

- Type I municipality

Chart 2: Use of professional services in the territory of Písek - a municipality with extended scope of operation (in absolute values). 


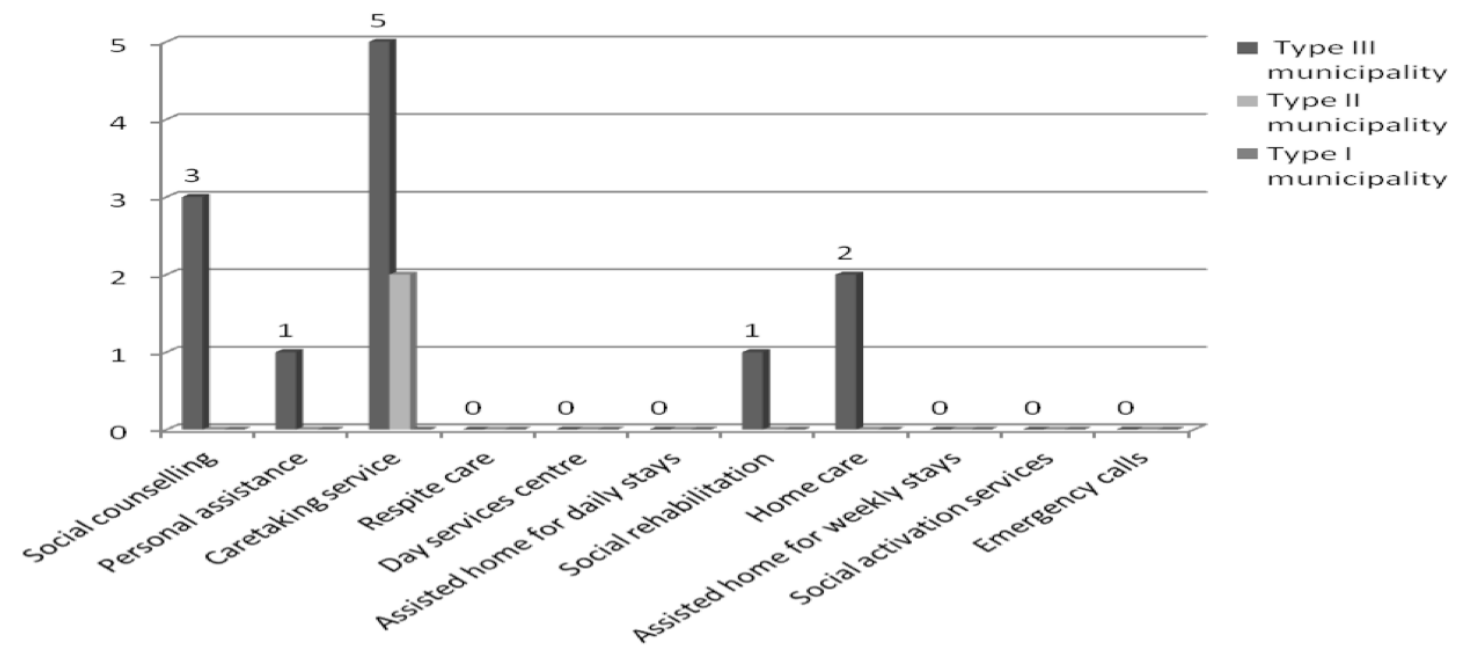

Chart 3: Representation of selected outpatient and field professional services for senior citizens in the territory of Písek - a municipality with extended scope of operation (in absolute values).

Source: Registry of social care providers in CR; status as of 30 Nov 2011.

personal counseling services. The least frequent answer by respondents (2) was that they are using the service of personal assistance or social rehabilitation (1). Home care is used by 23 respondents.

Chart 3 shows the structure of outpatient and field services for seniors in the region investigated. It is obvious that the services are most widely used in type III municipalities, i.e. the services of 12 selected providers of professional care. There is a dramatic difference in smaller municipalities, i.e. type II municipalities, where only two organizations provide care for their citizens through a caretaking service. In type I municipalities no provider of professional services was registered.

The data shown in the table clearly shows that over $80 \%(83.8 \%)$ of respondents prefer field services for

Table 1: Preferred form of Service Provision

\begin{tabular}{|c|c|c|c|}
\hline \multirow{2}{*}{ Total } & & Absolute frequency & Relative frequency \\
\cline { 3 - 4 } & & $\mathbf{4 7 5}$ & $\mathbf{1 0 0 \%}$ \\
\hline \hline Preferred form & Outpatient & 77 & $16.2 \%$ \\
\hline services & Field services & 398 & $83.8 \%$ \\
\hline
\end{tabular}

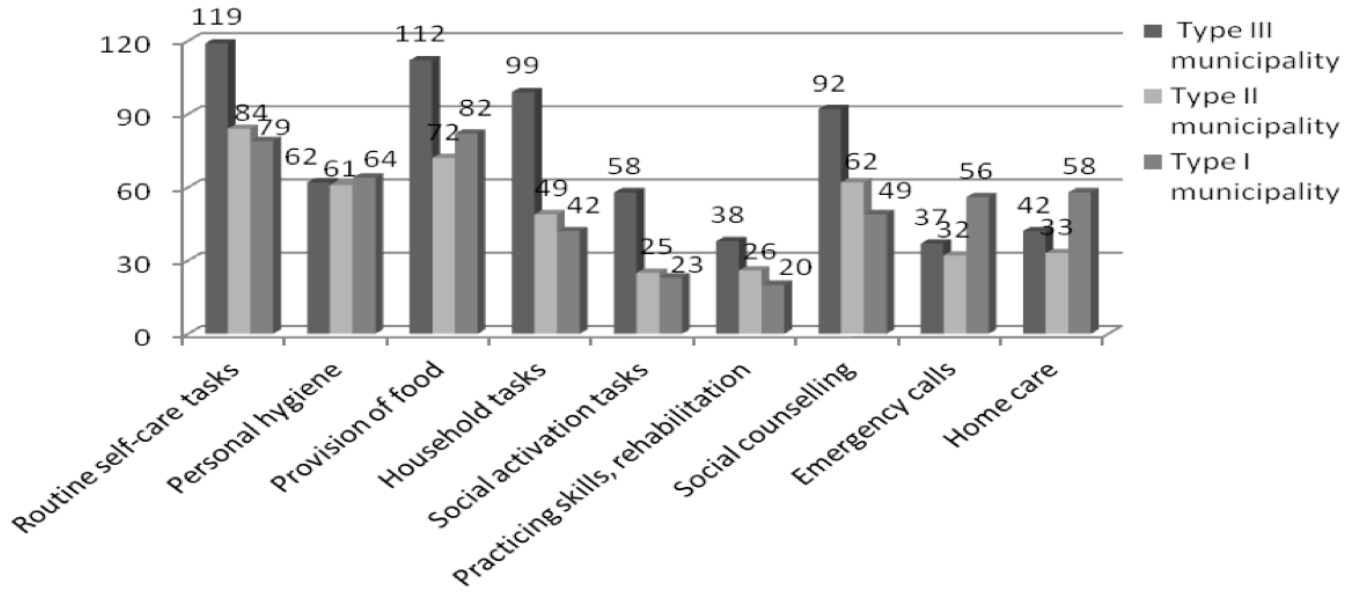

Chart 4: Requirements of family caretakers regarding professional services in the municipal territory of Písek - a municipality with extended scope of operation (in absolute values). 
Table 2: Possibilities of Temporary Stay of a Senior in an Assisted Home

\begin{tabular}{|c|c|c|c|}
\hline \multirow{2}{*}{ Total } & & Absolute frequency & Relative frequency \\
\cline { 3 - 4 } & & $\mathbf{4 7 5}$ & $\mathbf{1 0 0 \%}$ \\
\hline \hline Possibility of & Yes & 99 & $20.8 \%$ \\
\hline temporary stay & Rather yes & 108 & $22.7 \%$ \\
\hline & Rather not & 86 & $18.1 \%$ \\
\hline
\end{tabular}

seniors in their home environment, while the remaining respondents would rather use outpatient services.

Chart 4 captures respondents' opinions on the help provided by institutions to seniors in the natural environment of their homes. As the family caretakers would often use more than one of these services, the chart shows the frequency of answers given by the respondents.

The charts also clearly indicate that the most frequent requirement of family caretakers in type III municipalities was the need for handling everyday tasks such as food and household routines. In smaller, type II municipalities most respondents would make use of help with routine tasks, food and personal hygiene. In type I municipalities the most frequent requirement was the need for help with food provision, assistance with routine tasks and personal hygiene.

More than half of the family caretakers said that they had not or would not use the possibility of a temporary stay of a senior citizen in an assisted home. This option was even rejected by $38.4 \%$ of respondents.

The data in the table shows respondents' opinions on the choice regarding help to senior citizens. Most respondents $(45.3 \%)$ prefer respite care services. Day services centers enjoy less support among respondents (19.4\%). This option is closely followed by an assisted home for weekly stays, as reported by $18.7 \%$ of respondents. The least interest is shown in assisted homes for one-day stays - only $16.6 \%$ of respondents would choose them.

\section{DISCUSSION}

The research confirmed the past findings of the authors - e.g. [2, 4] - that the major feature of nonprofessional family caretakers is the prevalence of the female gender aged from 45 to 59 . Based on her own experience and secondary literature, the author points out that this major difference in gender is influenced by the traditional gender roles where women, not men, have had the status of caretaker in the family over the centuries. Women are willing to assume the caretaker role under diverse conditions and accept financial help from the state and their own long-term unemployment.

If the author shall assess how integrated forms of support to family caretakers of senior citizens are made use of in the territory of Písek - a municipality with extended scope of operation, then the results of the questionnaire-based investigation and data collected from publicly available resources show great differences in the representation of providers who can satisfy these needs. With respect to the findings, it can be noted that the providers of the field and outpatient services are concentrated mostly in Písek, a municipality with extended scope of operation (i.e. type III municipalities), where the most diverse and hence most widely used services are offered (Charts 2, 3). On the contrary, in smaller municipalities (i.e. type II and type I), only a narrow range of professional services is available or often no service at all (Chart 3). As a

Table 3: Choice of the Right Assisted Home for a Temporary Stay

\begin{tabular}{|c|c|c|c|}
\hline \multirow{2}{*}{ Total } & & Absolute frequency & Relative frequency \\
\cline { 3 - 4 } & & $\mathbf{4 7 5}$ & $\mathbf{1 0 0 \%}$ \\
\hline \hline Choice of an & Respite care & 215 & $45.3 \%$ \\
\hline assisted home & Day services centre & 92 & $19.4 \%$ \\
\hline & Home for one-day stays & 79 & $16.6 \%$ \\
\hline
\end{tabular}


result, the family caretakers provide constant assistance on the elementary level and, taking into account the various negative implications of diseases, they must bear the above-mentioned burden for years, along with efforts stemming from everyday care, only with the support of the family or mutual help from neighbors (Chart 1). The above-mentioned condition can be put into the context of the opinion of [2] who points out that care, especially if it is over the long turn, for the whole day and highly psychologically and physically demanding, poses a heavy burden for the caretaker. Family caretakers are therefore exposed to the threat of worsening family relationships, loss of friends, restrictions of social contacts and even social isolation, suffer from health problems and often face a difficult economic situation.

It is therefore unfair to expect families to take on this burden without any support of diverse kinds. Seniors and also non-professional caretakers should be provided with appropriate assistance to help them with everyday routines through professional services and adequate social security contributions. What needs to be highlighted above all is the important role of professional services that would be a great relief to family caretakers, because as found in the research, non-professional care providers can precisely define the services that can best help their senior citizens (Chart 4). These services are not, however, available to them, especially when they come from small villages and municipalities.

These facts reflect the data prepared by [15] who says that the development of field services within regional administrative entities is not receiving adequate support. To ensure that family care works as it should, a progressive and targeted development of the field forms of social services, mostly on the local and regional level [16] is highly desirable. If different sorts of supporting services are at hand, the senior or non-professional care providers will be able to choose what best fits them. The results summarized in Chart $\mathbf{4}$ match the trend of purposeful coordination between health and social services for those participating in the provision of assistance to disabled persons in their home environment.

Therefore, the author of this paper would like to recommend that municipal representatives map out the needs of senior citizens in the respective territory, increase awareness of the professional services offered (if available in the territory) and/or invest in their development. The aim is to ensure availability of at least the basic caretaking tasks in smaller municipalities and rural agglomerations, so that seniors can stay in their natural environment for as long as possible. The author would also like to point out the important role played by the mutual cooperation of the social care users, providers and ordering parties, and not only within the given region, in participating in social services community planning in respect to the future form of the services.

\section{CONCLUSION}

Today's society, and seniors' requirements primarily, create a growing pressure on such persons' need for care. Against the traditionally perceived obligation to provide care for relatives who cannot care for themselves, stands a view emphasizing the limits of this obligation and a "right" to pass on the obligation to specialized institutions and services. There remain, however, a substantial amount of people who choose to look after their seniors at home, despite the complex social, economic and health effects on the care provider himself and his closest environment. Even though many improvements have been made in the position of family care providers in the Czech Republic, there remains issues to be solved. The system of support for family care providers therefore needs to be further developed, so that this valuable source of care for people who cannot care for themselves, allows providing care within the family for as long as possible.

\section{REFERENCES}

[1] Válková $M$, Kojesová $M$, Holmerová I. Diskusní materiál k východiskům dlouhodobé péče v ČR. Praha: MPSV 2010; p. 40

[2] Tošnerová T. Pocity a potřeby pečujících o starší rodinné př́slušníky. Praha: Ambulance pro poruchy paměti a Ústav lékařské etiky 3. LF UK 2001; p. 5-11.

[3] Jeřábek H. () Rodinná péče o seniory jako „práce z lásky“: nové argumenty. Czech Sociol Rev 2009; 2(45): 264.

[4] Jeřábek $H$. Péče o staré lidi $v$ rodině. In: Jeřábek $H$, et al.: Rodinná péče o staré lidi. 1st. ed. Praha: CESES FSV UK 2005; pp. 10-13.

[5] Marin B, Leichsering K, Rodrigues R, et al. Who Cares? Care coordination and cooperation to enhance quality in elderly care in the European union. Discussion paper. Conference on Healthy and Dignified Ageing, 2009: 15-16 September Stockholm.

[6] Průša L, et al. Poskytování sociálních služeb pro seniory a osoby se zdravotním postižením. 1st. ed. Praha: VÚPSV, v.v.i. 2010; p. 244

[7] Molek J. Řízení organizací sociálních služeb - vybrané problem. Praha: VÚPSV, v.v.i 2011; p. 254.

[8] Bílá kniha v sociálních službách [online]. 26. 4. 2005 [cit. 2012-11-02]. Available at URL: http://www.mpsv.cz/ files/clanky/736/bila_kniha.pdf. 
[9] Šimák M. Sociální péče. In: Kahoun V, et al. Sociální zabezpečení: Vybrané kapitoly. 1st. ed. Praha: Triton 2009; p. 354.

[10] Veselá J. Sociální služby poskytované seniorům v domácnostech. Praha: VúPSV 2003; p. 50.

[11] Barvínková J. Rodinná péče a profesionální péče. In: Jeřábek $\mathrm{H}$, et al. Rodinná péče o staré lidi. 1st. ed. Praha: CESES FSV UK 2005; pp. 59-62.

[12] Jarošová D. Péče o seniory. Ostrava: Ostravská univerzita v Ostravě, ZSF 2006; pp. 41-62.

[13] Rummery K, Glendinning C. Primary Care and Social Services: Developing New Partnerships for Older People. UK: University of Manchester 2009; pp. 105-106.
[14] Leichsenring K. Developing integrated health and social care services for older persons in Europe [online]. 2004 [cit. 201211-02]. Available at URL: http://www.ncbi.nlm.nih.gov/pmc/ articles/PMC1393267/.

[15] Průša L. Vývoj vybavenosti regionů službami sociální péče pro seniory a osoby se zdravotním postižením. Kontakt 2011; 13(2): 157-65.

[16] Francová $H$, Novotný A. Podmínky péče o seniory se sníženou soběstačností $v$ kontextu současných změn. Kontakt 2008; 10(2): 334-38. 